\title{
Topological analysis of contemporary morphologies under conflict: The urban transformation of Dobrinja in Sarajevo
}

\author{
Inés Aquilué1, Estanislao Roca ${ }^{1}$, Javier Ruiz ${ }^{2}$ \\ 'Departament d'Urbanisme i Ordenació del Territori, Escola Tècnica Superior d'Arquitectura de \\ Barcelona, Universitat Politècnica de Catalunya. España \\ ${ }^{2}$ Departamento de Urbanismo y Ordenación del Territorio, Escuela Técnica Superior de \\ Arquitectura de Madrid, Universidad Politécnica de Madrid. España \\ E-mail: ines.aquilue@upc.edu, estanislao.roca@upc.edu,javier.ruiz@upm.es
}

\begin{abstract}
A topological analysis of urban systems under conflict have been carried out for developing new methodology in order to record and intervene in urban areas affected by uncertainty. In the present article the tested method is presented through the analysis of changes in a specific neighborhood in Sarajevo. This method analyses the transformation of urban areas in five consecutive phases: urban form [1], increase of uncertainty [2], application of the apparatus [3], change in urban form [4], information flows [5]. These five phases were applied to different empirical studies, analyzed through specific morphological and topological models. In the light of this method, a selected urban morphology (Dobrinja, a suburb in Sarajevo) has been examined. The urban morphology of the area was dramatically transformed as a consequence of the interethnic conflict. Dobrinja suffered severe modifications, first provoked by the violence of the siege during the Bosnian War (1992-1995), and then by the Inter-Entity Boundary Line as a result of the Dayton Peace Agreement (December 1995), which divided the neighborhood and caused serious alterations in its ethno-demographic and spatial structure. The morphological and topological analyses enabled us to determine the initial causes of these alterations and their spatial consequences in this urban area, during conflict and post-conflict stages.
\end{abstract}

Keywords: Sarajevo, Bosnian War, post-conflict planning, uncertainty, topological models, spatial network, divided urban areas, homogenization.

\section{Introduction}

As Karl Schlögel exposes in his work Im Raume lesen wir die Zeit (In Space We Read Time), the spatial condition could be crucial for the interpretation of history (Schlögel, 2003). Alterations in space are an expression of time and spatial changes could be indeed accelerated by historical events, especially in form of traumatic episodes. The city is constantly evolving, but in some occasions changes occur abruptly. Reading space is a complex and meaningful work. Urban form and topology should express not only the functionality, but also the social reproduction of space, by tackling the relationship between society and space (Hillier and
Hanson, 1984). Regarding this indissoluble relation, a new approach to urban changes has been developed thanks to a conceptual method based on changes in urban areas affected by conflicts. To analytically construct this conceptual method, we have developed a topological analysis in order to record urban evolution by adding its historical, political and social interpretation. The method is presented and applied to an urban area highly affected by uncertainty, violence and fear.

\section{Methodology}

In regard to the topological interpretation of space, this research aims to identify urban 
morphologies whose topology becomes increasingly decisive under high uncertainty. This topological approach has been applied to an evolutionary analysis of urban spaces under siege, fear and conflict, which conducted to the construction of a specific method.

The topological analysis is embodied in a conceptual framework, which analytically interprets the evolution of urban systems. This conceptual method analyses the transformation of urban areas in five consecutive phases: urban form [1], increase of uncertainty [2], application of the apparatus [3], change in urban form [4], information flows [5]. These five phases were applied to different empirical studies, analyzed through specific morphological and topological models. In the present article, one urban system is presented comparing phases [1] and [4], in which the change of the urban form and urban topology has been identified. Phases [2] and [3] are included as triggering phases but not developed methodologically. Phase [5] is incorporated as an outcome of the analysis.

To examine the city as a spatial network, we apply graph theory, which enables us to develop a spatial section of a city as a graph. A graph $\mathrm{G}$ is a pair of ordered sets $(\mathrm{V}, \mathrm{A})$, where the elements of A are two-element subsets of $\mathrm{V}$. The elements of $\mathrm{V}$ are called vertices and those of A edges. As we shall see, graphs are diagrams with nodes and lines, where nodes are vertices and lines are edges, connecting the corresponding vertices.

In Figure 1, graph $G$ represents the spatial relationship between road sections, delimited by two blocks. Graph I is an acyclic graph, which represents a building (Figure 1). Graph $G$ ' compiles the first network represented in $G$ with the addition of multiple graphs derived from I, which represent possible buildings adjacent to the different road sections. The example of Figure 1 have been reproduced subsequently in a larger scale to analyze complete urban systems, used as a topological representation of urban form.

The particular methodology developed in this research aims to examine evolutionary changes in cities. This method enables us to examine not only variations in urban form, but also alterations in its relational network, in its connectivity and in its adjacency, being key parameters to identify disturbances within the binomial space-society.

The above-mentioned conceptual method and the morphological and topological representations are applied to the system of Dobrinja, a neighborhood in Sarajevo. In Dobrinja, the Bosnian War and its post-conflict condition triggered an unexpected evolution. Thanks to the morphological and topological analysis of this urban system, it has been possible to identify which spatial changes took place since the beginning of uncertainty, and what kind of communication channels have recently been established between both sides of the border.

\section{Uncertainty and change in Dobrinja, Sara- jevo $1984-2016$}

In 1984, the Olympic neighbourhood of Dobrinja, consisting of juxtaposed residential
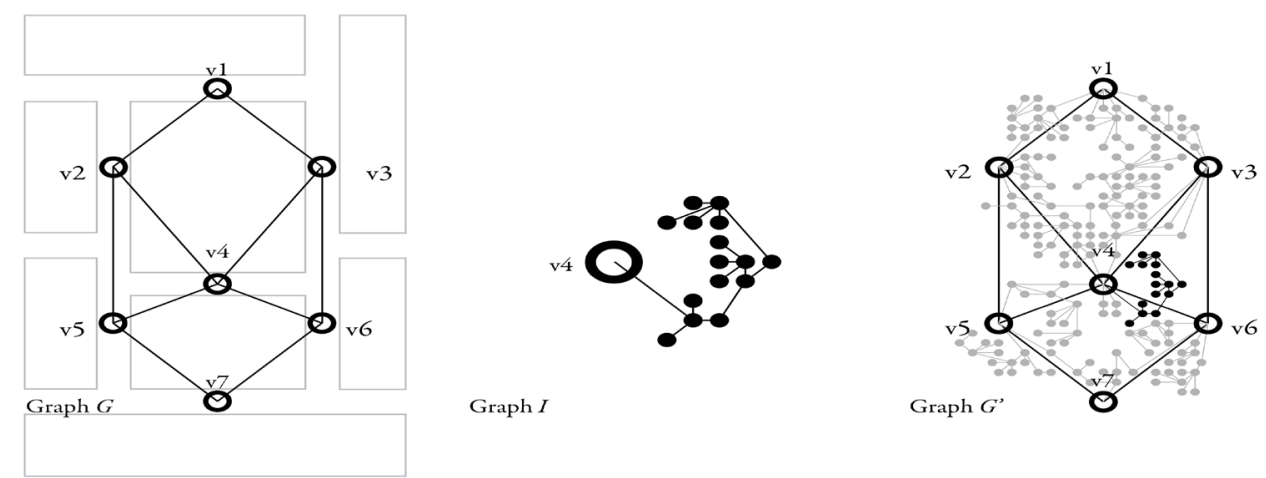

Figure 1. Graph $\mathrm{G}$ represents 8 blocks and their relational street network. Graph I is a topological representation of a building. Graph $G^{\prime}$ is a topological representation of 8 blocks, their adjacent streets and their adjacent buildings. Source: Inés Aquilué, 2012. 
blocks was built in Sarajevo and occupied by young Bosniak, Serbian and Croatian families. In 1992, the war broke out in Bosnia and Herzegovina and Sarajevo was besieged by the army of Republika Srpska. Dobrinja, located in an enclave near the airport (Figure 2), was besieged within the siege. It barely had any connections to the surroundings and its whole perimeter was on the front line. Following the war, Dobrinja was the only urban area in Sarajevo divided by the Inter-Entity Border Line and soon, the construction of a new residential area, known as East Sarajevo -result of the willingness to construct Serbian Sarajevo- began in its south-eastern limit. Since 1992, the neighborhood has undergone serious spatial alterations, initially triggered by the uncertainty provoked by the war. However, new changes took place after the conflict, this time due to spatial segregation caused by building a new area on the basis of ethnic homogenization.

\section{Urban form [Phase 1]: The disconnected construction of the socialist suburb}

The residential area of Dobrinja is a suburb placed in the southwest of Sarajevo, in a rural plain in front of the airport. The area (around $110 \mathrm{ha})$ was developed in low-rise and medium-rise buildings $(\mathrm{G}+3-8)$ and divided into five executive phases: Dobrinja I, II, III, IV and $\mathrm{V}$. Two smaller areas of duplex apartment buildings $(\mathrm{G}+2-3)$ were also constructed, occupying the area in front of the airport, quadrants $\mathrm{C} 4$ and $\mathrm{C}$ 5. In phases I to V, 9,000 dwellings were built, even though it was foreseen to construct 15,000 dwellings. According to Medić, the architect who designed the plan, the density of Dobrinja was calculated to be 320 people per hectare -or 80 dwellings per hectare- a low-medium density (Medić, 1984).

The type of building in the area was the variation of a similar pattern -except for quadrants $\mathrm{C} 4$ and $\mathrm{C} 5-$ (Figure 3). The linear blocks were formed through the adhesions of the same type of building with a central staircase and four dwellings ( $80 \mathrm{sqm}$ ) per floor. The front façade was separated from the road, leaving a space for the sidewalk, the green belt and the main pedestrian access. Thus, even though the buildings were aligned with the road, a distance in-between was preserved, which partially determined the almost exclusively residential character of Dobrinja. Moreover, ground floors varied depending on their location in the area. Dwellings occupied peripheral sections of the ground floors, whilst in the central areas were reserved for shops, business and studios. In all phases -Dobrinja I to $\mathrm{V}$-, a large part of blocks was designed using this basic type of building. A commercial boulevard with linear basement and direct contact with pedestrian sidewalk was projected in the central area.

The residential area was delimited by three parallel road axes in northwest-southeast direction, slightly rotated in regard to the linear implementation of the city, approximately $45^{\circ}$ clockwise (Figure 2). The southern axis defined the limit with the airport, whilst the northern axis bordered the hill of Mojmilo (Figure 3). The rest of the roads within the neighborhood, as well as the tributary of Dobrinja, which was canalized and rectified with a concrete basin and natural banks on each side, were planned regarding those perimeter axes. Both perimeter axes connected Dobrinja with the rest of the city. The location of Dobrinja not only defined the end of the planned city, but its dislocated and outlying position also meant limited connection to Sarajevo. This particular situation would determine its physical role during the Bosnian War, as well as its placement between the military barracks of Lukavica and the airport (Figure 3).

\section{Increase of uncertainty [Phase 2]: The siege of Dobrinja within the Bosnian War}

The Siege of Sarajevo initiated as soon as Alija Izetbegović declared the independence of Bosnia and Herzegovina in April 1992, after holding a referendum (Donia, 2006: 277279). As a reprisal, some paramilitary Bosnian Serb groups took the hills around Sarajevo and besieged the city, cutting communications and services. A double process of survival began: the life under siege of snipers and the lack of every single type of supplies and provisions. The armored aggression immersed the whole 


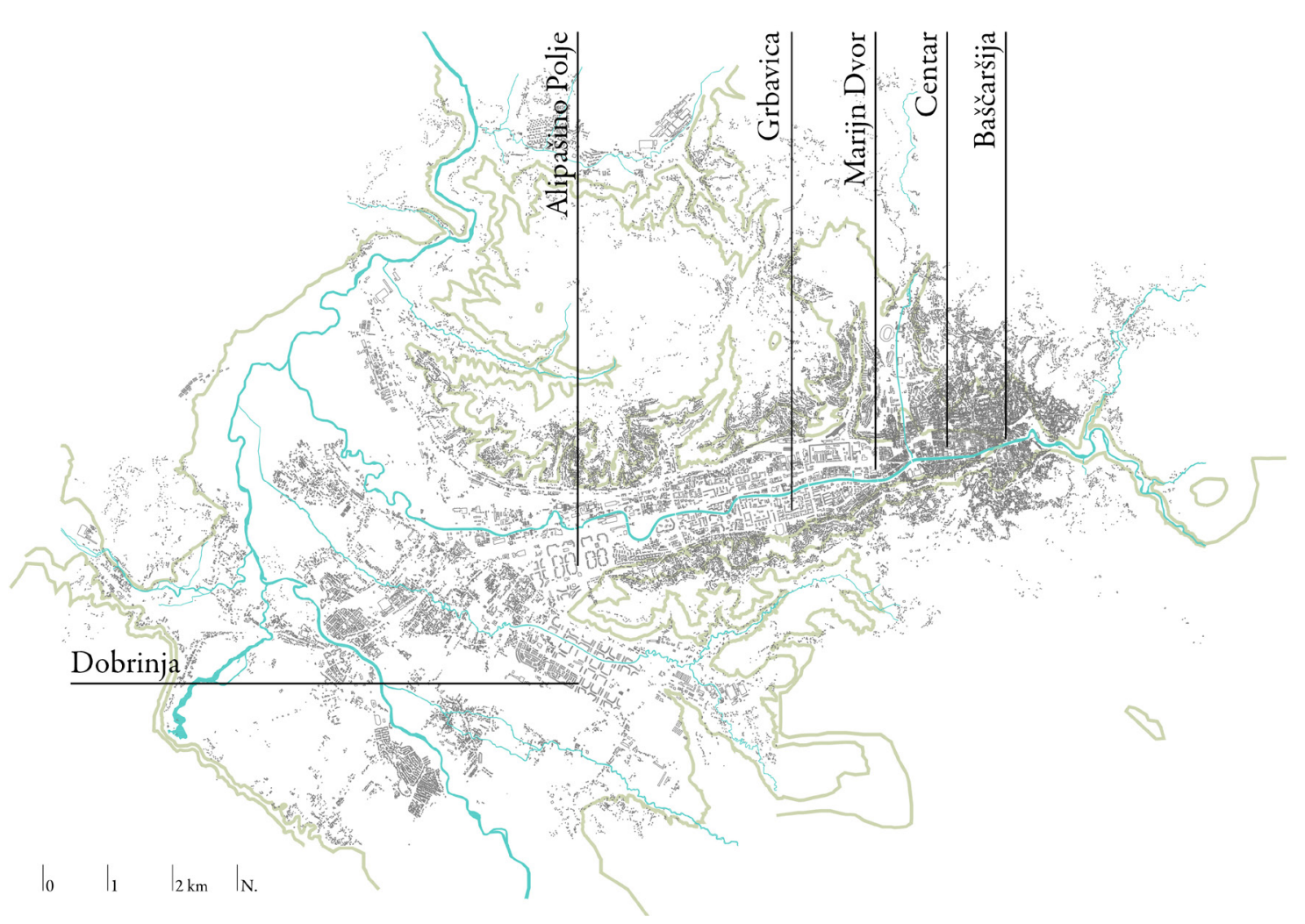

Figure 2. Location of Dobrinja as a suburb of Sarajevo. Source: Inés Aquilué, 2016.

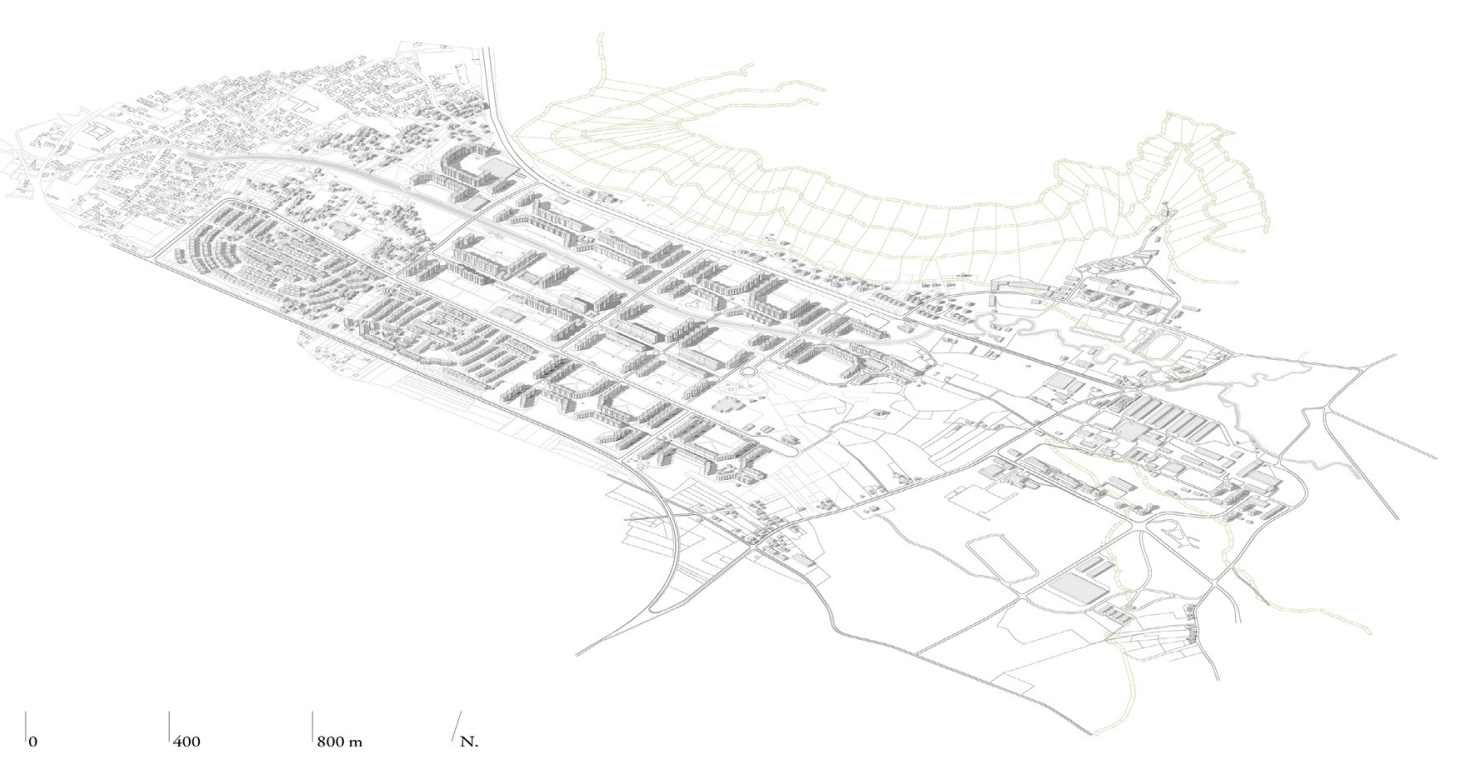

Figure 3. Morphological model of the neighborhood of Dobrinja in 1992, before the war. To the southeast the barracks of Lukavica. Source: Inés Aquilué, 2016. 
city into almost four years of scarcity and violence, where civilians were the regular target of besiegers -mainly composed by the Army of Republika Srpska (Vojska Republike Srpske, hereinafter VRS) and some old members of the Yugoslav People's Army (Jugoslovenska Narodna Armija, hereinafter JNA). The besiegers were under the political imaginary of Radovan Karadžić, an ideal that attempted to eradicate a part of the population in its own territory and to destroy historical ties between the humans and the place.

The emergence of Bosnian Serb troops around the hills created the first interethnic border in the city, which despite some variations along the siege, would maintain the division between the area controlled by the VRS and the area under control of the Army of the Republic of Bosnia and Herzegovina (Armija Republike Bosne i Hercegovine, hereinafter ARBiH), named free zone.

Geographical features of Sarajevo determined the siege. Its condition as a longitudinal city, annexing different neighborhoods within a narrow valley surrounded by hills, facilitated the position of the troops and their view onto civilian targets (Aquilué and Roca, 2014; Aquilué et al., 2014-2015; Ristić, 2011). Besides, the physical location of Dobrinja captured aggressors' attention. The VRS had military interest in Dobrinja (closeness to bases and armament storages, such as Lukavica), territorial interest (closeness to the main airport) and social interest (betweenennes to residential areas occupied by VRS). Therefore, even though the neighborhood was never fully occupied, it was besieged and nearly cut off from the rest of the city, and its boundaries were utterly destroyed -especially quadrant C4, Dobrinja I and IV (Bublin, 2006).

Genocide and urbicide were the double purpose of the siege (Shaw, 2004), both conducted until the built environment, which enabled the heterogeneity required for the reproduction of the social system, was destroyed. It was a strategy not only for eradicating urban citizens but also for redefining Sarajevo's urban structure that once made heterogeneity possible. The strength of the discourse of homogenization, applied as "ethnic cleansing" based on hatred of otherness, grew in the fear of uncertainty. In the discourse on homogenization, there was an intrinsic claim to prioritize ethnicity over territory. Its destruction was a means to an end, in which homogeneity of urban population was equated with physical and symbolic space.

These discourses started at the end of the 1980 s, in a process of ethnic securitization, first guided by homogenization discourses and followed by violence based on fear. Bosnian leaders promulgated homogeneity as the condition that would allow individual security. It represented security for a theoretically homogeneous group at the expense of eradicating other heterogeneous groups through fear, uncertainty and anxiety of security threats. The desire for division and physical homogenization remained and altered the space of Dobrinja, once the violent uncertainty decreased and the siege of the city was over.

\section{Application of the apparatus [Phase 3]: Eth- nic homogenization and the division of Do- brinja}

In November 1995, more than three years after the outbreak of violence, the aggression against Sarajevo began to calm down due to ceasefire negotiations. The peace agreement was signed in Dayton (Ohio, US) by the presidents of the Republic of Bosnia and Herzegovina, Republic of Croatia and of the Federal Republic of Yugoslavia (Serbia and Montenegro) -Alija Izetbegović, Franjo Tuđman and Slobodan Milošević. Besides, in order to put an end to the conflict, the state of Bosnia and Herzegovina was internally divided into two new entities, the Federation of Bosnia and Herzegovina and the Republika Srpska. The political and territorial bases of both entities were included in the General Framework Agreement for Peace in Bosnia and Herzegovina -better known as Dayton Peace Agreement (hereinafter DPA)-, where the boundary between the Republic and the Federation was designated: the Inter-Entity Boundary Line (hereinafter IEBL) (UN 1995, Bose 2002).

In the city of Sarajevo, the IEBL sectioned part of its outskirts, reducing its influence on the suburbs and some of its less populated 
municipalities. On the Federation side, the Canton of Sarajevo replaced the old city of Sarajevo, resulting in the loss of $39 \%$ of its territory, whilst in the Republika Srpska the new city of East Sarajevo was created. Analogously to what happened at state level, the area of the old city of Sarajevo - previously made up by 10 municipalities- was divided into two halves, and this division led to an alteration in its regional ethnicity composition. A region formerly composed of three major ethnic groups, was transformed into two administrative regions -the Canton of Sarajevo with Bosniak majority, and East Sarajevo with Serbian majority. This reorganization into ethnically self-enclosed sectors resulted from a process of regrouping of ethnic redoubts who felt insecure. This fear-propelled process had already begun at the outset of the war with the discourses of homogenization.

Dobrinja was the only neighborhood in urban Sarajevo divided by the IEBL. The IEBL was drawn on a 1:600,000 scale map, designed in Dayton and afterwards redrawn to a 1:50,000 scale map, elaborated by the UNPROFOR. In Dobrinja, the drawing of the IEBL did not show enough detail to determine its accurate and valid position. Indeed, an imprecise spatial resolution did not solve the conflict established in 1996 (whether the boundary should coincide with the war front line). Consequently, the Office of the High Representative (hereinafter OHR) - the highest international body in Bosnia-Herzegovina- had to intervene to define the location of the IEBL in Dobrinja. In April 2001, the final line was defined by the Arbitration Award for Dobrinja I and IV, and four buildings (around 370 dwellings) from Dobrinja were ceded to the Republika Srpska (Sheridan, 2001).

Once the Arbitration Award was decreed and the border was drawn, the Republika Srpska determined different territorial schemes to delimit East Sarajevo. New buildings emerged on the area adjacent to Dobrinja and the old military barracks of Lukavica. Its legal construction was possible after a change in planning statements that led to the abrogation of old plans. The application of the apparatus was initiated -in Foucauldian terms (Foucault, 1977)- and new regional planning led to a new urban form, highly determined by the IEBL.

\section{Change in urban form [Phase 4]: The con- struction of East Sarajevo}

The final drawing of the IEBL brought about the set of regional and regulation plans for the new urban center on the east side of the IEBL, bordering Dobrinja. Whilst the modifications of the urban form in the Federation area were practically null, a new building process started on the east side. On the Republika Srpska side, in East Sarajevo, specific urban regulation plans, which could be overwritten if necessary, enabled rapid development of the area. Figure 4 shows the development of the IEBL eastward, on the site of the former military barracks of Lukavica, where blocks of continuous façades and open inner courtyards were built.

Since the adoption of the first urban regulation plan in 2001, it has been estimated that between 2,300 and 2,700 dwellings were built in East Sarajevo. Dwellings previously belonging to Dobrinja (370 dwellings), dwellings in the barracks of Lukavica (around 300 dwellings) and single-family houses built before the war on rural plots (around 40-50 dwellings) should be added to determine the total number of dwellings in the new urban area. According to the morphological model, it is estimated that there were between 3,000 and 3,400 dwellings, with approximately $8,500-9,500$ residents in the whole area (200 ha included in the first regulation plan). The ground floors of the new residential streets were partially occupied by services (shops, cafes, restaurants, pharmacies, banks, etc.), and five shopping areas (supermarket type), as well as a cultural center, a library, three primary schools and various sports areas were built or rehabilitated. In the northeast area of East Sarajevo some industrial warehouses denote the transitional state of Lukavica from military-industrial area to urban or residential center. Similarly, the undeveloped rural plots show a transitional appearance from rural to urban environment, since the whole area is still under process of stabilization (Figure 5). 


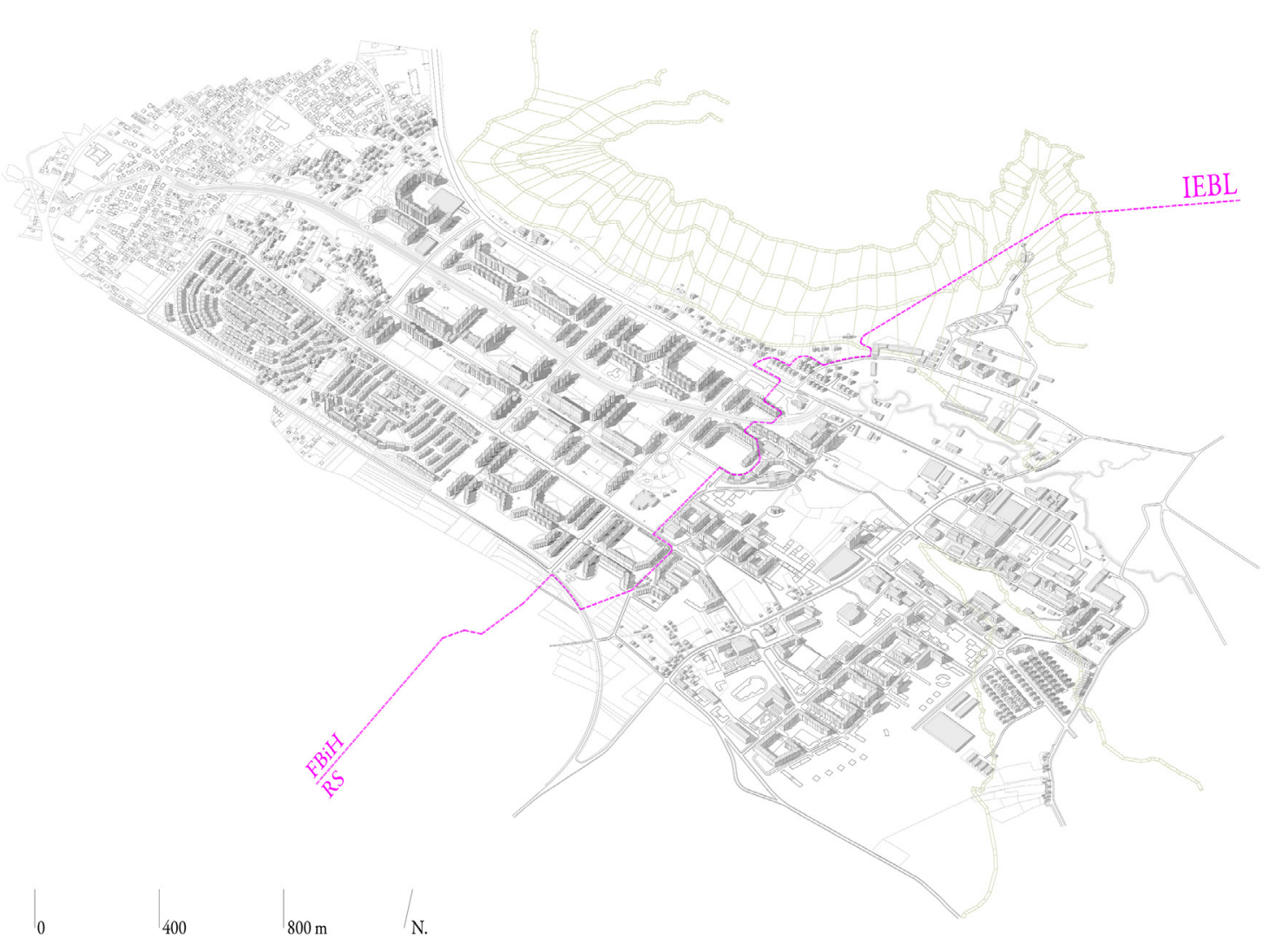

Figure 4. Morphological model of Dobrinja and Lukavica in 2016. Source: Inés Aquilué, 2016.

The topological model of Dobrinja from 2016 reflects serious changes that affect its eastern border due to the drawing of the IEBL (Figure 6). In Figure 6, the new connections - new public roads and accesses to new buildings- are represented in magenta. In the area of the Federation there is no change in the urban fabric, except for the trolleybus station installed before reaching the border line. The buildings of Dobrinja I and Dobrinja IV ceded to the Republika Srpska have been reconnected with new roads and with buildings constructed on the eastern side (pre-existing vertices $n 24, x 6, n 23, v 3, n 13$ and n12). The newly built networks have greater robustness and higher density of public space, as shown by the number of edges incident on new vertices (in magenta). However, the new network is strongly connected in the eastern area, whilst it remains hardly linked to the Federation area. The strongest path between both sides of the IEBL is defined by vertices $v 2, v 3, x 8, v 5$ and $\mathrm{x} 13$. As shown in Figure 6, the connectivity network has been altered since the new built areas are all linked within the limits of East Sarajevo in the Republika Srpska.

\section{Information flows [Phase 5]: The future of Dobrinja and East Sarajevo}

The ethnic structure in the urban area bordering Dobrinja and Lukavica has been severely affected by the IEBL. The 2013 census -results published in 2016- showed a clear trend towards ethnic homogenization not only of East Sarajevo, but also of the entire Republika Srpska (Agencija za statistiku Bosne i Hercegovine, 2016: 54). This tendency 


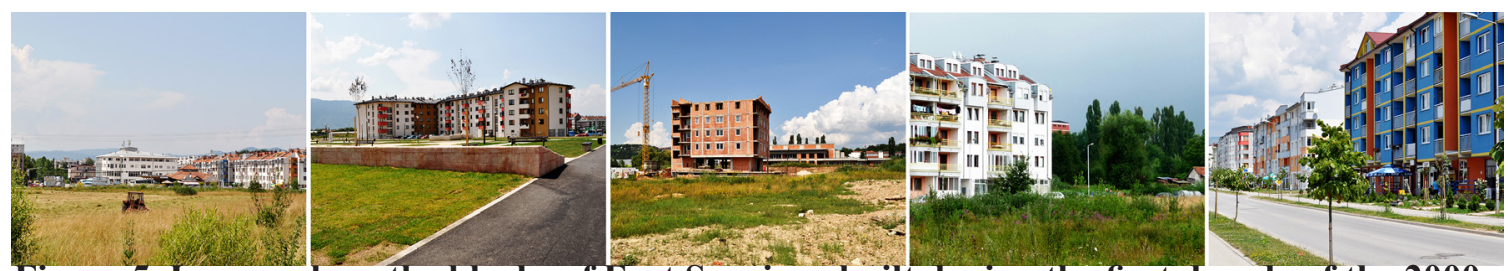

Figure 5. Images show the blocks of East Sarajevo built during the first decade of the 2000s. Source: Inés Aquilué, 2014.

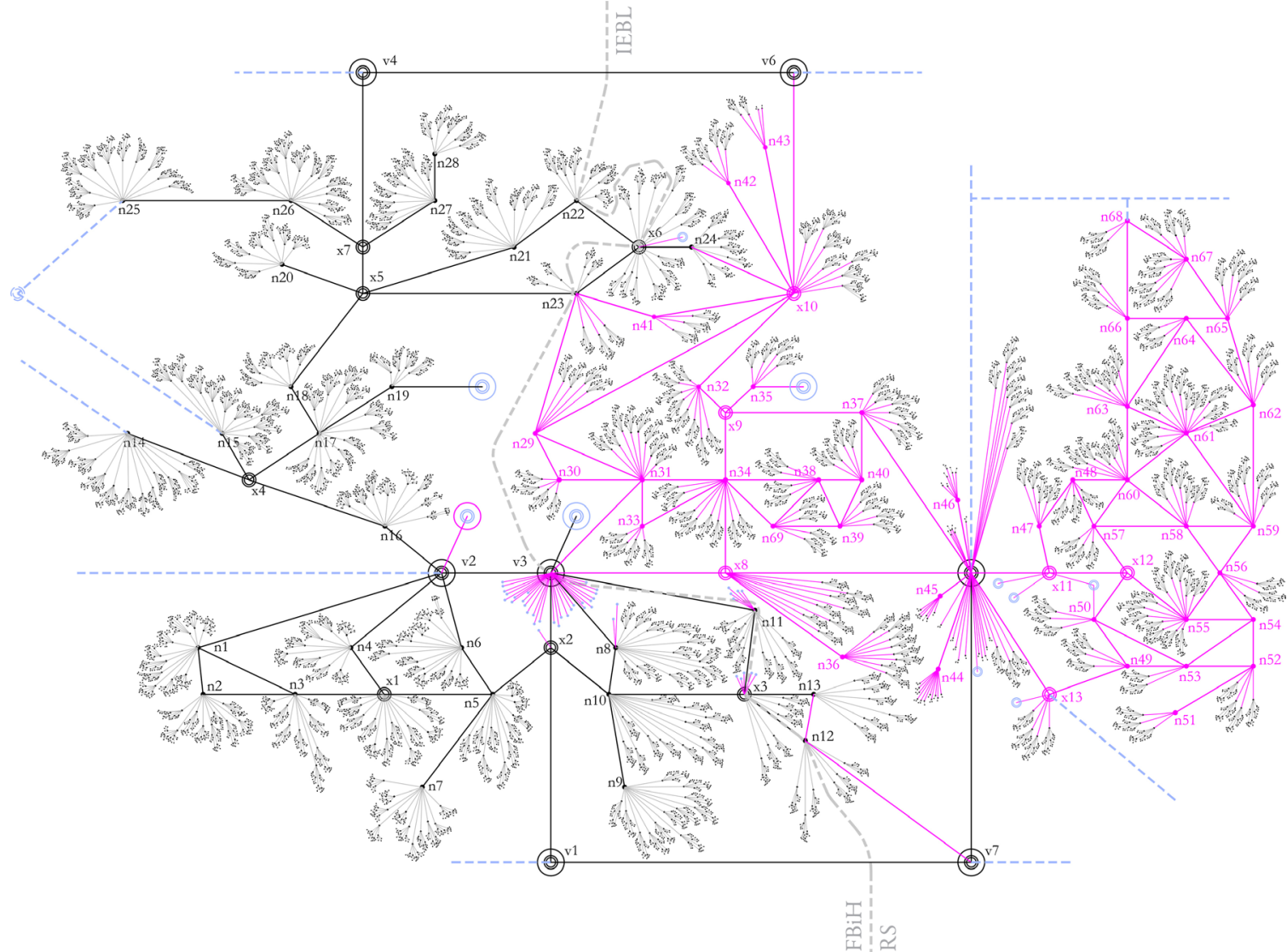

Figure 6. Topological model of eastern blocks of Dobrinja and Lukavica. In black and grey the spatial network before the war, in magenta the new spatial network constructed in East Sarajevo. Source: Inés Aquilué, 2016.

follows the political ideology that guides the government of Republika Srpska and which is moving towards the division of the State of Bosnia-Herzegovina. However, there are still some links between both sides (Figure 6), which are becoming necessary paths of functional exchange.

The future of Dobrinja and Lukavica has been severely altered in recent decades. Security discourses of ethnic homogenization have had consequences in demographic distribution and spatial construction. However, more than twenty years after the end of the Bosnian War, the possible futures of the neighborhood are still uncertain. Despite the political tendency to ratify the division through social simplification and the homogenization of the areas adjacent to Dobrinja, the economic and geographical reality on both sides seems to be more complex. Hence, the absolute disconnection does not seem to be an imminent reality, despite the induced weakness of the common network. 


\section{Conclusion}

Changes in Dobrinja have been recorded thanks to morphological and topological models. Besides, variations in urban form and in its spatial network have been historically and politically interpreted using a conceptual method. This analysis has enabled us to elaborate a spatial reading of historical context, on a specific urban area dramatically affected by violence and fear. Broader research showed that this conceptual method and its inherent morphological and topological models are valuable tools for evaluating change in space triggered by uncertainty. Analysis of abrupt changes in cities should be considered as a key for developing a theory on urban resilience, led by a holistic understanding of urban systems (Rogers, 2012). Topological interpretation of space added a layer of relational information that overlaps with spatial and social features. The resilience of cities relies on urban evolution in contexts of distress and space should be included in its dimension.

\section{References}

Arbour \& Associés (2001) Faubourg Québec, paramètres de développement urbain (Société de développement de Montréal, Montréal).

Agencija za statistiku Bosne i Hercegovine (2016) Popis stanovništva, domaćinstava i stanova u Bosni i Hercegovini, 2013. Rezultati popisa / Cenzus of population, households and dwellings in Bosnia and Herzegovina, 2013. Final results (Agencija za statistiku Bosne i Hercegovine, Sarajevo).

Aquilué, I. and Roca, E. (2014) 'Sarajevo, de la autoorganización durante el sitio de la ciudad a la duplicidad administrativa después del conflicto', Scripta Nova. Revista Electrónica de Geografía y Ciencias Sociales XVIII (493), 1-18.

Aquilué, I., Leković, M. and Ruiz, J. (20142015) 'Urban Trauma and Self-organization of the City. Autopoiesis in the Battle of Mogadishu and the Siege of Sarajevo', Urban 8-9, 63-76.
Aquilué, I. and Roca, E. (2016) 'Urban planning after the Bosnian War: The division of regional territory in Sarajevo', Cities 58, 152-163.

Bose, S. (2002) Bosnia after Dayton: Nationalist partition and International intervention (Hurst \& Company Publishers, London).

Bublin, M. (2006) Sarajevo u istoriji: od neolitskog naselja do metropolisa (Buybook, Sarajevo).

Coward, M. (2009) Urbicide: The politics of urban destruction (Routledge, London and New York).

Donia, R. J. (2006) Sarajevo a Biography (Hurst \& Company, London).

Foucault, M. (1977) 'Le jeu de Michel Foucault', Ornicar? Interview with Michel Foucault published on July 10, 1977.

Harary, F. (1969) Graph Theory (AddisonWesley Publishing Company, Boston).

Hillier, B. and Hanson, J. (1984) The social logic of space (Cambridge University Press, Cambridge).

Medić, M. (1984) 'Naselje novinara Dobrinja II / The press village of Dobrinja II', in Radović, R. (ed.) Arhitektura i UrbanizamAU 94/95 (Arhitektura i Urbanizam, Belgrade) 56-57.

Rogers, P. (2012) Resilience \& the city: change, (dis)order and disaster (Routledge, London and New York).

Schlögel, K. (2003) Im Raume lesen wir die Zeit. Über Zivilisationsgeschichte und Geopolitik (Carl Hanser Verlag, Munich and Viena).

Shaw, M. (2004) 'New Wars of the City: Relationships of "Urbicide" and "Genocide", in Graham, S. (ed.) Cities, war and terrorism: Towards an urban geopolitics (Blackwell Publishing, Oxford) 141-153.

Sheridan, D. P. (2001) Arbitration Award of Dobrinja I and IV (Office of the High Representative, Sarajevo).

UN (1995). General Framework Agreement for Peace in Bosnia and Herzegovina (Dayton Peace Agreement). (UN-Department of Political Affairs).

Wagensberg, J. (1985) Ideas sobre la complejidad del mundo (Tusquets Editores, Barcelona). 